\title{
A study on the influence of tides on the water table conditions of the shallow coastal aquifers
}

\author{
C. Singaraja ${ }^{1} \cdot$ S. Chidambaram ${ }^{2} \cdot$ Noble Jacob $^{3}$
}

Received: 3 August 2015 / Accepted: 27 December 2017 / Published online: 24 January 2018

(C) The Author(s) 2018. This article is an open access publication

\begin{abstract}
Tidal variation and water level in aquifer is an important function in the coastal environment, this study attempts to find the relationship between water table fluctuation and tides in the shallow coastal aquifers. The study was conducted by selecting three coastal sites and by monitoring the water level for every 2 -h interval in $24 \mathrm{~h}$ of observation. The study was done during two periods of full moon and new moon along the Cuddalore coastal region of southern part of Tamil Nadu, India. The study shows the relationship between tidal variation, water table fluctuations, dissolved oxygen, and electrical conductivity. An attempt has also been made in this study to approximate the rate of flow of water. Anyhow, the differences are site specific and the angle of inclination of the water table shows a significant relation to the mean sea level, with respect to the distance of the point of observation from the sea and elevation above mean sea level.
\end{abstract}

Keywords Tide $\cdot$ Water table $\cdot$ Coastal aquifers $\cdot$ Dissolved oxygen $\cdot$ Electrical conductivity $\cdot$ Rate of flow

\section{Introduction}

Water levels in aquifer are a significant parameter in groundwater hydrology and a careful and detailed analysis of its spatio-temporal variation reveals useful information on the coastal aquifer system. Various causes affecting the groundwater levels are groundwater withdrawals, rainfall recharge, evapotranspiration, interaction with surface water bodies, etc. Ocean tides are also known to affect the groundwater fluctuation in the coastal aquifers (Kim et al. 2008). The water level fluctuations can be due to two different factors; the first one is anthropogenic. It is well known that the groundwater withdrawal from an aquifer or from a field of

C. Singaraja

geolionking@gmail.com

S. Chidambaram

chidambaram_s@rediffmail.com

Noble Jacob

noblej@barc.gov.in

1 Department of Geology, Presidency College, Chennai 600005, India

2 Department of Earth Sciences, Annamalai University, Annamalai Nagar, Chidambaram 608002, India

3 Isotope Production and Applications Division, Bhabha Atomic Research Centre, Mumbai 400 085, India wells induces water level decline creating a cone of depression depending, among other parameters, on the aquifer hydrodynamic parameters and geometry. But, after the pumping is stopped, the level starts coming up due to recuperation to attain equilibrium. The second one cause able to induce daily water level fluctuations is the tides. Actually, the effect of tides has been observed in the groundwater level fluctuation of an aquifer, if monitored continuously or at a shorter interval (Kim et al. 2006; Wang et al. 2015). The dilatation of the Earth due mainly to the position of Moon and Sun induces measurable water level fluctuations in the well (Davies 2014). In addition, most of the previous research, including the mixing of seawater/freshwater studies, has focused on the behavior of the water table in coastal beaches. All these works were concerned particularly with the relationship between tides and beach water tables emphasizing the tidal-induced fluctuations of the water table near the shore and the consequences for processes affecting beach stability. None of them give an accurate picture of rate of flow and inclination of the water level to the mean sea level near the sea boundary. Dissolved oxygen, electrical conductivity, Turbidity play a significant role in the determination of the water quality (Davies and Ugwumba 2013; Davies 2014). It is also known as re-oxygenating and photosynthetic processes in water are a most important indicator of coastal aquifer quality (Praveena et al. 2013). 
A limited number of researchers have attempted to model the physics of groundwater flow processes in beaches. Ashtiani et al. (2001) used an implicit finite-difference numerical solution of the simulate beach water table response to tidal forcing. Kim et al. $(2006,2008)$ used a time-series monitoring model to solve the beach water-table response to tidal fluctuations. A review on the tidal studies (Table 1) shows that, multifaceted approaches have been adapted to understand the tidal zone dynamics. Usually, regional groundwater flow and contaminant transport studies in the vicinity of the coastal zone assume that the coastal boundary water level is equivalent to the mean sea level and that tidal- and wave induced variations have negligible effect. This study aims in understanding the relation between water table, dissolved oxygen and electrical conductivity in the coastal aquifers and tidal influence in selected three locations in the coastal alluvial aquifers. The tidal- water table behavior was studied for two different periods during New moon (NM) and Full Moon (FM).

\section{Study area}

The study area lies between $\left(11^{\circ} 37^{\prime} 4^{\prime \prime}\right)$ to $\left(11^{\circ} 45^{\prime} 2^{\prime \prime}\right)$ North latitude and $\left(79^{\circ} 44^{\prime} 18^{\prime \prime}\right)$ to $\left(79^{\circ} 47^{\prime} 46^{\prime \prime}\right)$ East Longitude (Fig. 1). It falls in survey of India map 56M/10 and 14. The study area is predominantly agricultural in nature along the coastal. The three location chosen for study falls near the tide dominated region demarcated from the toposheets. The location are Devanampatnam ( $79^{\circ} 47^{\prime} 19^{\prime \prime}$ and $\left.11^{\circ} 44^{\prime}\right)$, Rajapettai $\left(79^{\circ} 46^{\prime} 22^{\prime \prime}\right.$ and $\left.11^{\circ} 40^{\prime} 55^{\prime \prime}\right)$ and Tiyagavalli $\left(79^{\circ} 45^{\prime} 38^{\prime \prime}\right.$ and $11^{\circ} 37^{\prime} 14^{\prime \prime}$ ) of which the first two station are located very near to the coast 513 and $460 \mathrm{~m}$, respectively, and Tiyagavalli is at a greater distance $(700 \mathrm{~m})$ compared to the other two station.

The study area receives rainfall of about $1050 \mathrm{~mm}$ to about $1400 \mathrm{~mm}$. The locations are covered by unconsolidated eastern coastal plain, which is predominantly occupied by the flood plain of fluvial origin formed under the influence of Penneyar, Vellar and Coleroon river systems. The unconsolidated quaternary alluvium is underlined by

Table 1 Study on Literature of tidal in the different parts of the world

\begin{tabular}{|c|c|c|c|}
\hline S. no. & Authors and year & Area & Remark \\
\hline 1 & Wolaver et al. (1983) & Lower Chesapeake Bay & $\begin{array}{l}\text { Tidal exchanges of nitrogen and phosphorus between a mesohaline } \\
\text { vegetated marsh }\end{array}$ \\
\hline 2 & Simmons et al. (1988) & Virginia Waters & $\begin{array}{l}\text { The role of submarine groundwater discharge in transporting nutri- } \\
\text { ent flux to coastal marine environments. }\end{array}$ \\
\hline 3 & Harvey and Odum (1990) & Virginia & $\begin{array}{l}\text { Influence of tidal marshes on upland groundwater discharge to } \\
\text { Estuaries }\end{array}$ \\
\hline 4 & Cheng and Chen (2001) & Shandong Province & Three dimensional modeling, Jahe River basin, Shandong province \\
\hline 5 & Srinivas and Dinesh Kumar (2002) & Southwest coast of India & Tidal and non-tidal respect to water condition \\
\hline 6 & Barlow (2003) & Atlantic coast & $\begin{array}{l}\text { Ground water in fresh water-salt water environments of the Atlan- } \\
\text { tic Coast }\end{array}$ \\
\hline 7 & Westbrook et al. (2005) & Western Australia & $\begin{array}{l}\text { Tidally forced estuarine boundary, Canning River, Western Aus- } \\
\text { tralia }\end{array}$ \\
\hline 8 & Vethamony et al. (2005) & Gulf of Kutch & Tidal eddies in a semi-enclosed basin \\
\hline 9 & Eriksson et al. (2006) & South Africa & An unusual fluvial to tidal transition in the mesoarchean \\
\hline 10 & Mao et al. (2006) & Ardeer, Scotland & Tidal influence on behavior of a coastal aquifer \\
\hline 11 & Marcello and Mauro (2007) & Mediterranean Sea & Tidal, seiche and wind dynamics in a small lagoon \\
\hline 12 & Ramaswamy et al. (2007) & Gulf of Kachchh & Source and dispersal of suspended sediment in the macro-tidal \\
\hline 13 & Li et al.(2008) & Shallow beach & $\begin{array}{l}\text { Tide-induced seawater-groundwater circulation in shallow beach } \\
\text { aquifers }\end{array}$ \\
\hline 14 & Kim et al. 2008 & Jeju Island, Korea & Multi-depth monitoring at a multilayered coastal aquifer \\
\hline 15 & Manoj et al. (2009) & West Coast, India & Tidal asymmetry in the mandovi and zuari estuaries \\
\hline 16 & Sridevi et al. (2010) & East coast of India & Internal waves on sound propagation \\
\hline 17 & Singaraja (2011) & Southeast coast of India & A study on the influence of tides on the water table conditions \\
\hline 18 & Mitra et al. (2011) & West Bengal, India & Spatial and tidal variations of physico-chemical parameters \\
\hline 19 & Praveena et al. (2013) & Strait of Malacca, Malaysia & Assessment of tidal and anthropogenic impacts on coastal waters \\
\hline 20 & Simon Peter et al. (2014) & Southeast of Tamil Nadu, India & Tidal effects on sandy marine beach \\
\hline 21 & Wang et al. (2015) & Coast & $\begin{array}{l}\text { Modeling study of the potential water quality impacts from tidal } \\
\text { energy }\end{array}$ \\
\hline
\end{tabular}



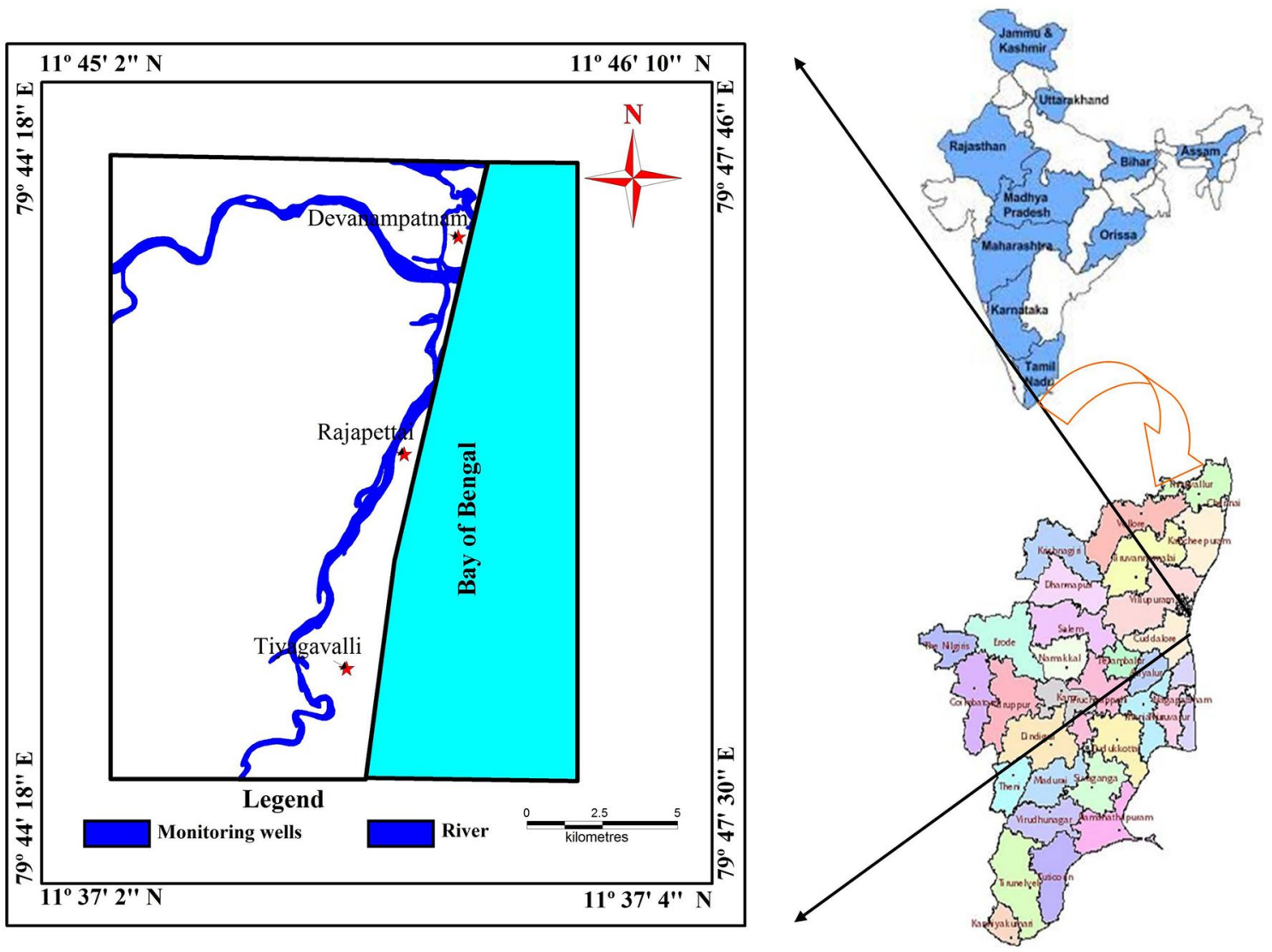

Fig. 1 Monitoring well of the study area

the Cuddalore sandstone forming the principal and potential aquifers of the region (Chidambaram et al. 2010; Singaraja et al. 2014). Ground water occurs in recent Alluvial formation. The studies on the impact of tides were attempted on the coastal alluvial aquifer only. The water level at Devanampatnam ranges from 2.59 to $2.80 \mathrm{~m}$, at Rajapettai it ranges from 0.98 to $3.05 \mathrm{~m}$ and the water level at Tiyagavalli ranges 2.71-3.05 m (mbgl).

\section{Methodology}

The influence of the tidal area was demarcated from the toposheets and sites were selected. Three wells at Devanampatnam, Rajapettai, and Tiyagavalli were observed for water level fluctuations using water level sensor. The observations were carried out in 2-h interval for $24 \mathrm{~h}$ in the field. The tidal observation stations are present at Nagapattinam in the south and at Chennai in the north. Since the study area falls between these two regions the tidal range has been calculated using TIDECAL software. The tidal values obtained were specific to the particular latitude and longitude and to the time of field observation for the specific areas. The rate of flow of water through the observation wells were approximately calculated using the Darcy's law principle. The inclination of the water table to the MSL was calculated by simple Pythagoras method. All the parameters were observed and analyzed for two different periods full moon (FM) and new moon (NM). The date and time of the observation schedule is given in Table 2 .

\section{Result and discussion}

\section{Water level fluctuations}

The water level indicates the piezometric balance of the groundwater with the atmosphere. The variation of the groundwater level indicates the rate of inflow and out flow across a particular well. The data observed in the Devanampatnam well during both the periods indicate that there is an increase of water level from 14:00 to $08.00 \mathrm{~h}$, subsequently there is a decrease in the water level beyond this in both the time periods of observation (Fig. 2). It is also interesting to note that water level is shallow during the FM compared the NM, though the pattern remains the same. The water level 
Table 2 Details of sample locations and Time

\begin{tabular}{|c|c|c|c|c|c|}
\hline \multicolumn{2}{|l|}{ Devanampatnam } & \multicolumn{2}{|l|}{ Rajapettai } & \multicolumn{2}{|l|}{ Tiyagavalli } \\
\hline New moon & Full moon & New moon & Full moon & New moon & Full moon \\
\hline Date January/20/2015 & Date January/05/2015 & $\begin{array}{l}\text { Date Febru- } \\
\text { ary/18/2015 }\end{array}$ & $\begin{array}{l}\text { Date Febru- } \\
\text { ary/03/2015 }\end{array}$ & Date March/20/2015 & Date March/05/2015 \\
\hline Time (h) & Time (h) & Time (h) & Time (h) & Time (h) & Time (h) \\
\hline $12: 00$ & $18: 00$ & $14: 00$ & 16:00 & 20:00 & 20:00 \\
\hline $14: 00$ & 20:00 & $16: 00$ & 18:00 & $22: 00$ & $22: 00$ \\
\hline $16: 00$ & $22: 00$ & $18: 00$ & $20: 00$ & $24: 00$ & $24: 00$ \\
\hline $18: 00$ & $24: 00$ & $20: 00$ & $22: 00$ & 02:00 & 02:00 \\
\hline $20: 00$ & 02:00 & $22: 00$ & $24: 00$ & 04;00 & 04:00 \\
\hline $22: 00$ & 04:00 & $24: 00$ & 02:00 & 06:00 & 06:00 \\
\hline $24: 00$ & 06:00 & 02:00 & 04:00 & 08:00 & 08:00 \\
\hline 02:00 & 08:00 & 04:00 & 06:00 & $10: 00$ & $10: 00$ \\
\hline 04:00 & $10: 00$ & 06:00 & 08:00 & $12: 00$ & $12: 00$ \\
\hline 06:00 & $12: 00$ & 08:00 & $10: 00$ & $14: 00$ & $14: 00$ \\
\hline 08:00 & $14: 00$ & $10: 00$ & $12: 00$ & $16: 00$ & $16: 00$ \\
\hline $10: 00$ & $16: 00$ & $12: 00$ & $14: 00$ & $18: 00$ & $18: 00$ \\
\hline $12: 00$ & $18: 00$ & $14: 00$ & $16: 00$ & 20:00 & 20:00 \\
\hline
\end{tabular}

fluctuation during the period of observation is about $0.06 \mathrm{~m}$ in FM and $0.08 \mathrm{~m}$ in NM.

The water level observations in the Rajapettai shows similar trend as that of Devanampatnam, but the variation in the elevation of water level is lesser and a parallelism is maintained (Fig. 2). The water level has been lowered to a maximum from the initial reading to a depth of about $0.06 \mathrm{~m}$ in FM and $0.08 \mathrm{~m}$ in NM.

The water level observations of the Tiyagavalli indicate a different trend that the NM water level is higher than the FM water level (Fig. 2). The increase of water level is noted from 20:00 to the 08:00 h. The pattern of decrease of water level further does not show steady parallelism. Water level is higher during the NM though the trend of increase in water level remains the same in the both periods. The water level has been lowered to a maximum from the initial reading to a depth of about $0.07 \mathrm{~m}$ in FM and $0.09 \mathrm{~m}$ in NM (Fig. 2). Due to the water table-dependent transmissivity of an unconfined aquifer, the sea tide has an enhancing effect on the mean water table (Philip 1973 Kim et al. 2008).

\section{Tidal variation}

The tidal curve of the Full moon and the New moon at Devanampatnam indicates that there is a symmetrical crest and trough (Fig. 3) and it is also noted that the tidal fluctuation is diurnal with time in $6 \mathrm{~h}$ interval. The highest $(1.06 \mathrm{~m}$ AMSL) and the lowest tide level (0.21 m AMSL) are noted in the NM than the FM. The lowest tide and the highest tide in both FM and NM are noted at 02:0 and 08:0 h, respectively. The figure also indicates that the fluctuation is more during the NM than the FM. It is interesting to note that the tidal height is lesser in FM from 20:00 to 02:00 h, when compared to NM, but after 02:00 h the tidal height of FM increases than that of the NM and again after 08:00 h the tidal height of the FM decreases than the NM. Hence there is a cyclic decrease and increase of the tidal height which is alternatively witnessed in both NM and FM.

The tidal observations made at Rajapettai are similar to Devanampatnam, the tidal curve of the Full moon and the New moon indicates that there is a symmetrical crest and trough (Fig. 3) and it is also noted that there is a tidal fluctuation with time in 6-h interval. The highest (1.08 $\mathrm{m}$ amsl) and the lowest tide level $(0.24 \mathrm{~m}$ amsl) are noted in the NM than the FM. The lowest tide and the highest tide in both FM and NM are noted at 02:00 and 08:00 h, respectively. The figure also indicates that the fluctuation is more during the NM than the FM. It is interesting to note that the tidal height is lesser in NM from 18:00 to 24:00 h, when compared to FM, but after 24:00 h the tidal height of NM increases than that of the FM. Duration of a high and low water is also affected by local conditions (Manoj et al. 2009; Wang et al. 2015). But for a given location the high water will always lag the passage of the Moon by a fixed amount of hours (this is known as "the establishment of the port").

The tidal observations made at Tiyagavalli, is also similar to Devanampatnam and Rajapettai, the tidal curve of the Full moon and the New moon indicates that there is a symmetrical crest and trough (Fig. 3) and it is also noted that there is a tidal fluctuation with time in 6-h interval. 

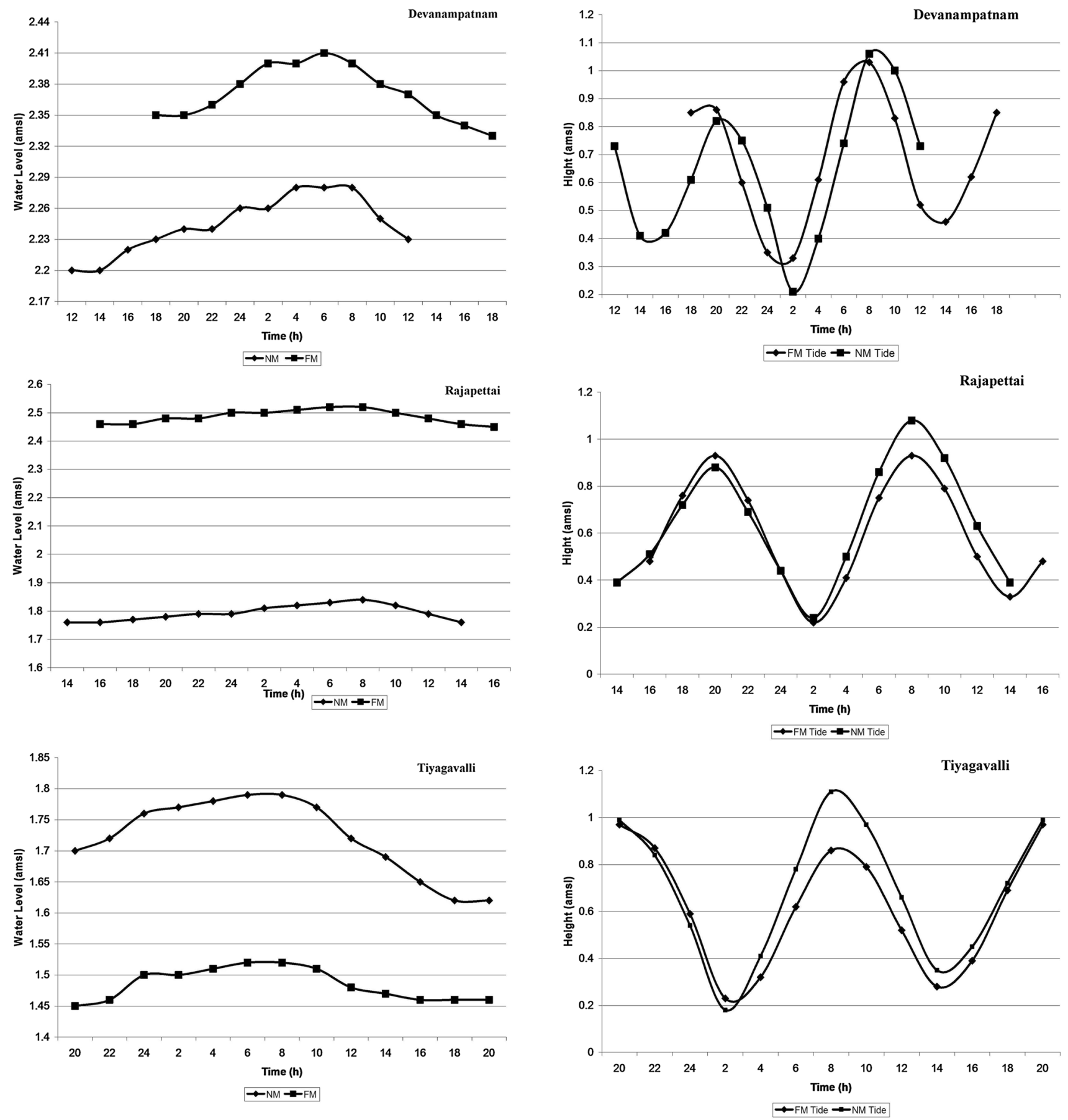

Fig. 2 Water level fluctuations during FM and NM at Devanampatnam, Rajapettai and Tiyagavalli (all values in amsl)

Fig. 3 Tidal Variation during FM and NM at Devanampatnam, Rajapettai and Tiyagavalli (amsl)

The highest $(1.11 \mathrm{~m} \mathrm{amsl})$ and the lowest tide level $(0.18 \mathrm{~m}$ amsl) were noted in the NM similar to the other stations. The lowest tide and the highest tide in NM are noted at 02:00 $\mathrm{h}$ and 08:00 am, respectively, and at FM the lowest is at 02:00 $\mathrm{h}$ and the highest at 20:00 h. The figure also indicates that the fluctuation is more during the NM

than the FM. It is interesting to note that the tidal height is lesser in NM from 20:00 to 02:00 h, when compared to FM, but after 02:00 h the tidal height of NM increases than that of the FM. The fluctuation is more during the NM than the FM. 


\section{Water level and tidal influence}

Tidal forcing of adjacent groundwater is a common feature in coastal environments and can be an important mechanism of pore water movement in saturated and intertidal zones (Hughes et al. 1998). In shallow unconfined aquifers, tidal forcing can enhance the extent of saltwater ingress and can also alter the configuration of solute concentration contours, particularly near the top of the water table (Ashtiani et al. 1999; Davies 2014). The tidal cycling shows water level variation in the coastal region within the 24:00 h observation. There is an increase of $0.06 \mathrm{~m}$ of water level at the Devanampatnam coast during the Full Moon and $0.08 \mathrm{~m}$ increase in New Moon (Fig. 4). A study on the comparison between the water level variation and the tidal variation shows that the water level
Fig. 4 Water level and Tidal Influence during FM and NM at Devanampatnam (amsl)
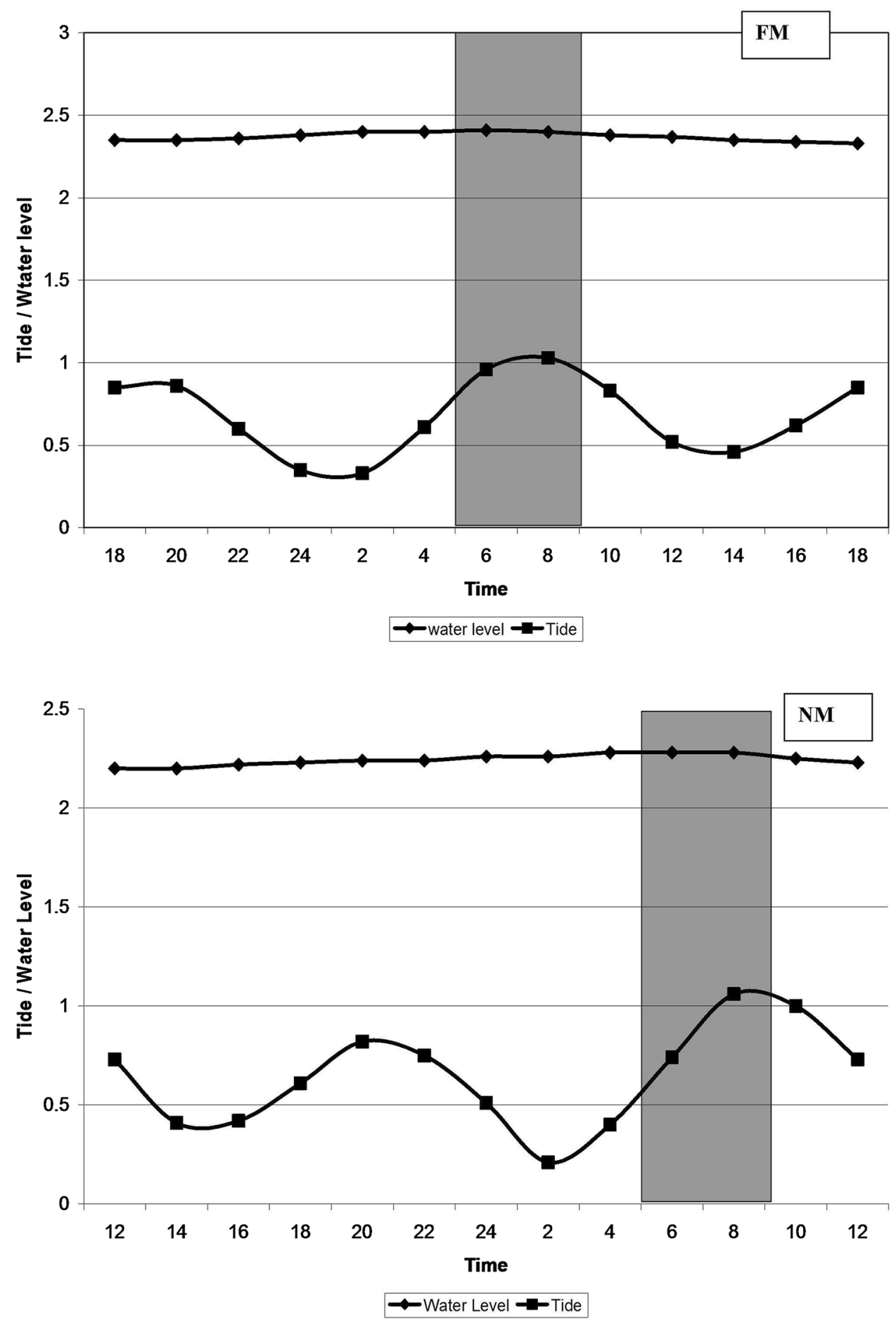
increase corresponds to the increase of tidal height around $8.00 \mathrm{am}$. Similarly the variation of water level in Rajapettai is $0.06 \mathrm{~m}$ during FM and 0.08 during NM (Fig. 5). At Tiyagavalli the variation of water level is $0.07 \mathrm{~m}$ at FM and $0.09 \mathrm{~m}$ at NM. Comparing FM and NM in all the three stations the water level variations is about $0.02 \mathrm{~m}$; further the greater variation in water level is noted in new moon period in all the stations and the highest in Tiyagavalli
(Fig. 6). It is located near a river creek of Uppanar influenced by tides, but it is comparatively far from the sea with results in the time log. In general the water level increases around 08:00 $\mathrm{h}$ in all the station during both the periods of observation and the sinusoidal nature observed in tide is not well reflected in the water level though a minor increase in water level is noted at the time of high-tide.
Fig. 5 Water level and Tidal Influence during FM and NM at Rajapettai (amsl)
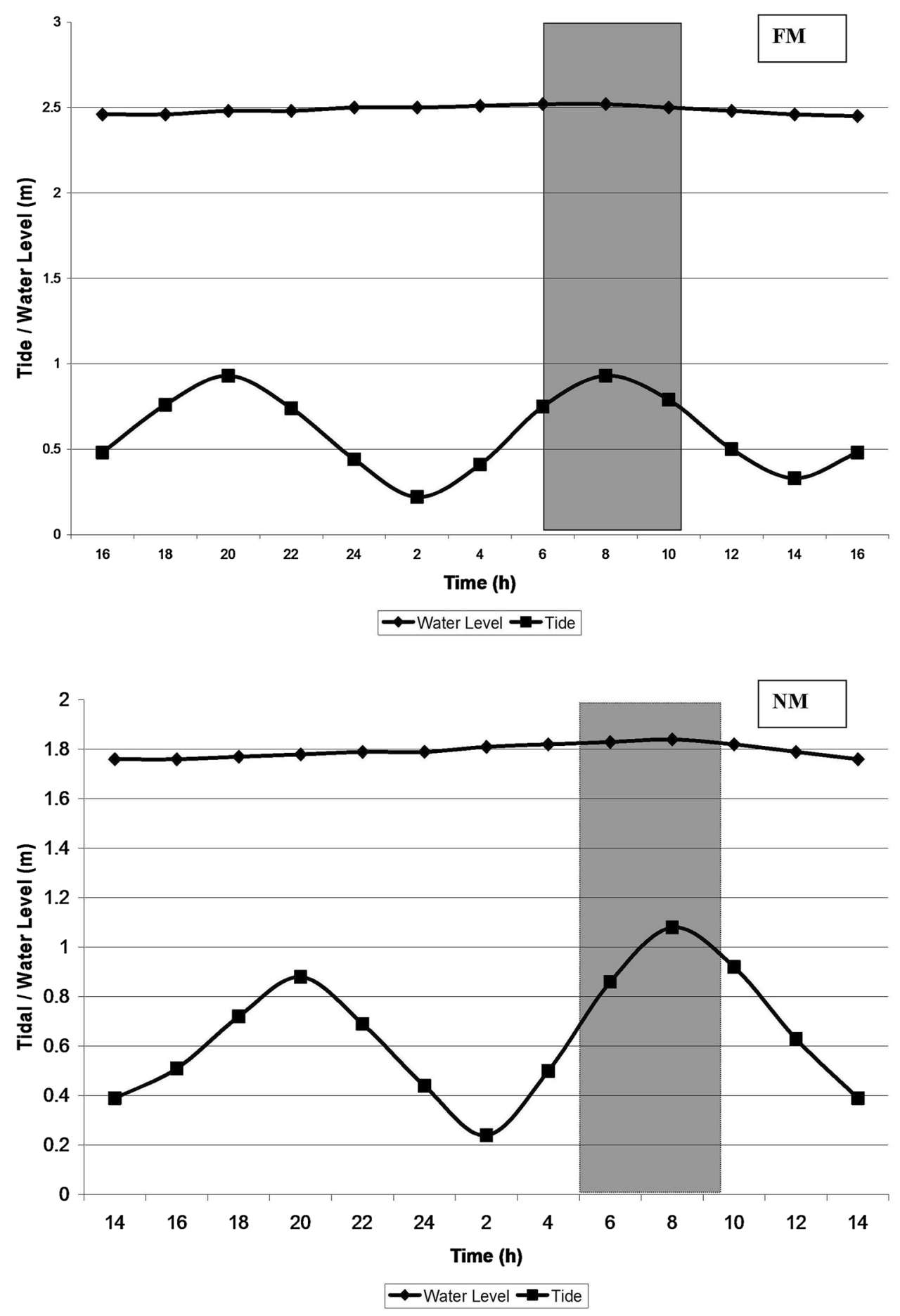
Fig. 6 Water level and Tidal Influence during FM and $\mathrm{NM}$ at Tiyagavalli (amsl)
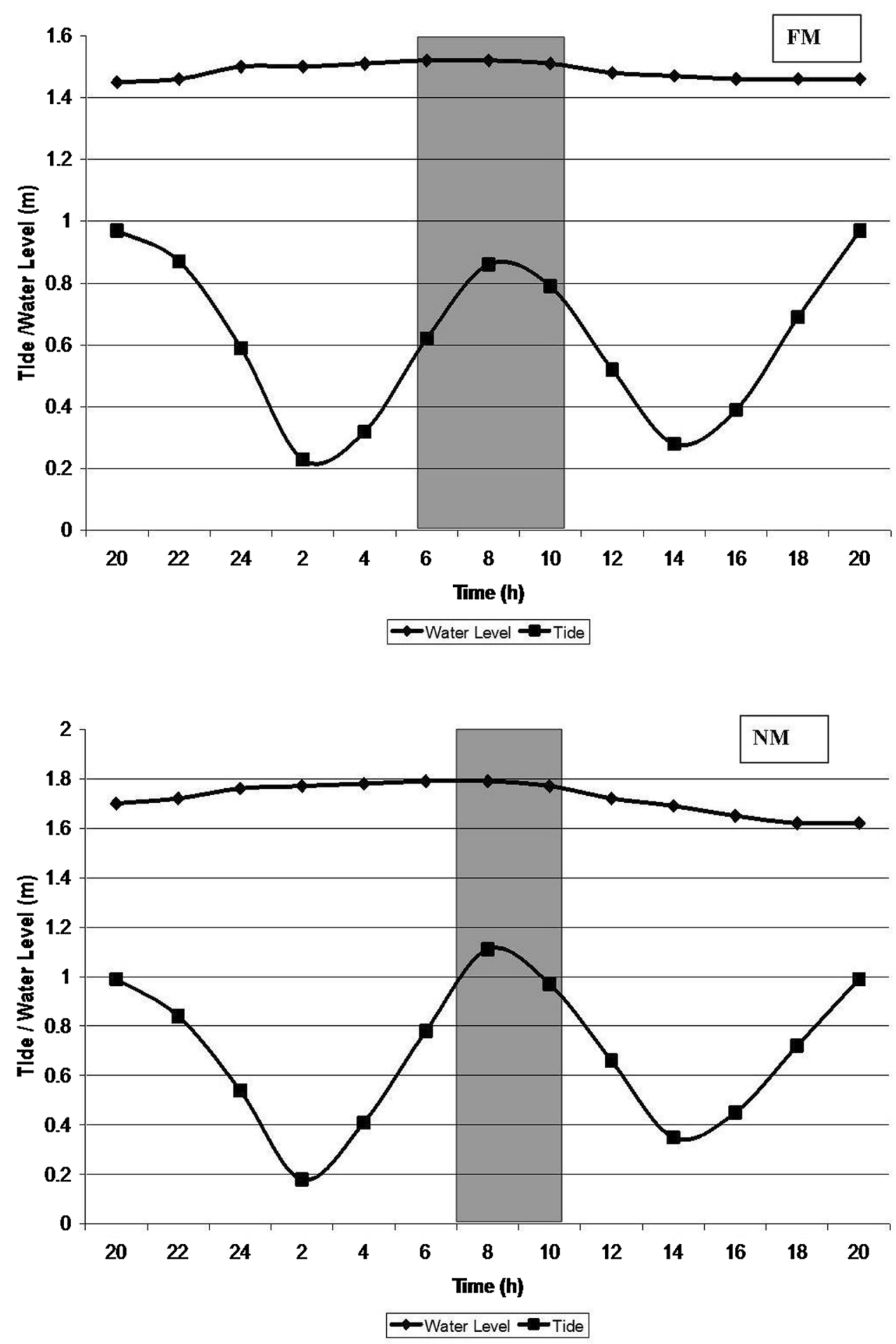

\section{Rate of flow}

Hydrologists have traditionally applied Darcy's Law to describe the freshwater flow resulting from measured hydraulic gradients. However, when comparisons have been made, the modeled outflow is often much less than what is actually measured (Smith and Zawadzki 2003). Hence attempts have also been made using law to calculate the water flow in this region.

Assuming that the groundwater flows from the land to the sea with the available data the rate of flow at a particular point and its variation with time was also attempted. The Mean sea level at Devanampatnam is $5 \mathrm{~m}$, the water level observed during FM is $2.35 \mathrm{~m}$ and that of $\mathrm{NM}$ is 
$2.2 \mathrm{~m}$, the distance from well to sea is $513 \mathrm{~m} \mathrm{(dL);} \mathrm{Raja-}$ pettai mean sea level $3.5 \mathrm{~m}$ (water level varies from $2.46 \mathrm{~m}$ during FM to $1.76 \mathrm{~m}$ in $\mathrm{NM}$ ) and distance from well to sea $460 \mathrm{~m}$; at Tiyagavalli mean sea level $4.5 \mathrm{~m}$ (water level varies from $1.45 \mathrm{~m}$ during FM, $1.7 \mathrm{~m}$ in $\mathrm{NM}$ ) and distance from well to sea $700 \mathrm{~m}$ (Fig. 7). The flow of water through an aquifer is governed by Darcy's law, which states that the rate of flow is directly proportional to the hydraulic gradient (Harvey and Odum 1990)

$Q=K \mathrm{~d} h / \mathrm{d} L$,

where $Q$-rate of flow, $K$-hydraulic conductivity, m/day (concent values) ( $K$ is a hydraulic conductivity for an alluvial sandy aquifer is taken as $12 \mathrm{~m} /$ day (Morris and Johnson, 1967), $\mathrm{d} h$-Mean sea level and $\mathrm{d} L$ - distance between well and sea).

Field studies of the groundwater discharge process in unconfined coastal aquifers show that the tide can significantly influence the temporal and spatial patterns of groundwater discharge as well as the salt concentration in the near-shore groundwater (Robinson and Gallagher 1993; Robinson et al. 1998).

The rate of flow of water was calculated from the hydraulic gradient $(\mathrm{d} h / \mathrm{d} L)$ considering the hydraulic conductivity of the sandy aquifer as $12 \mathrm{~m} /$ day (Morris and Johnson 1967). The calculated results for Devanampatnam show that the rate of flow of water increases till 08:00 $\mathrm{h}$ in the morning. It starts decreasing thereon, during both the periods of observation. The range of flow rate of groundwater during full moon is $0.045-0.047 \mathrm{~m} /$ day and that during New moon is $0.043-0.044 \mathrm{~m} /$ day. The rate of flow is higher during FM than NM (Fig. 8).
The rate of flow of water in Rajapettai also shows similar pattern to Devanampatnam, during both the periods of observation (Fig. 8). The range of flow rate of groundwater during full moon is $0.063-0.065 \mathrm{~m} /$ day and that during new moon is $0.045-0.048065 \mathrm{~m} /$ day. The trend of rate of flow is similar to that of Devanampatnam. The rate of flow of water in Rajapettai is higher than Devanampatnam.

The observation well at Tiyagavalli shows that the rate increases till 08:00 $\mathrm{h}$ and then starts decreasing, during both the periods of observation similar to the other two sites. The range of flow rate of groundwater is during full moon is $0.018-0.019 \mathrm{~m} /$ day and that during New moon is $0.02-0.022 \mathrm{~m} /$ day. The rate of flow is higher during NM than FM. In other two stations the rate of flow is higher during FM, but at Tiyagavalli the rate of flow is higher during NM (Fig. 8). Variation in hydraulic head in the underlying aquifer was small over the tidal cycle (Harvey et al. 1987) and some seasonal variation was apparent; hydraulic heads in the aquifer were highest in full moon and lowest in new moon at Devanampatnam and Rajapettai, but Tiyagavalli is contrary due to the greater distance from ocean.

\section{Influence of EC and DO on coastal aquifers}

DO, EC, tides and water level fluctuation are significant parameters in groundwater dynamics for the most part shallow coastal aquifers. Tides are also to affect the groundwater fluctuation, EC, and DO in the coastal region (Davies 2014). Devanampatnam and Rajapettai (Fig. 9) wells shows that the water level, DO, and EC value revealed significant changes during the monitoring period. There is an increase of tide, water level, and EC at Devanampatnam and Rajapettai during the $\mathrm{NM}$ and FM around 08:00 $\mathrm{h}$, but corresponds to the

Fig. 7 Rate of flow

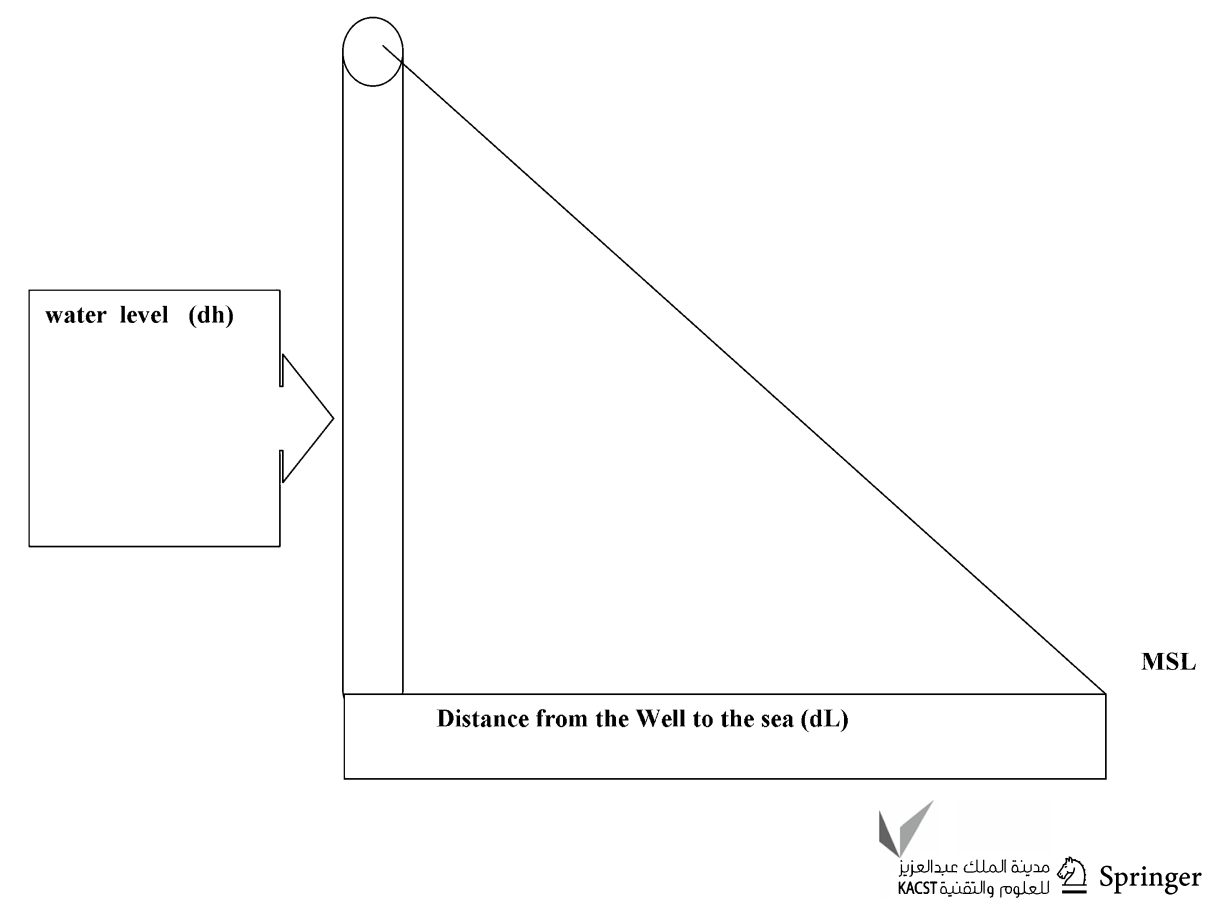



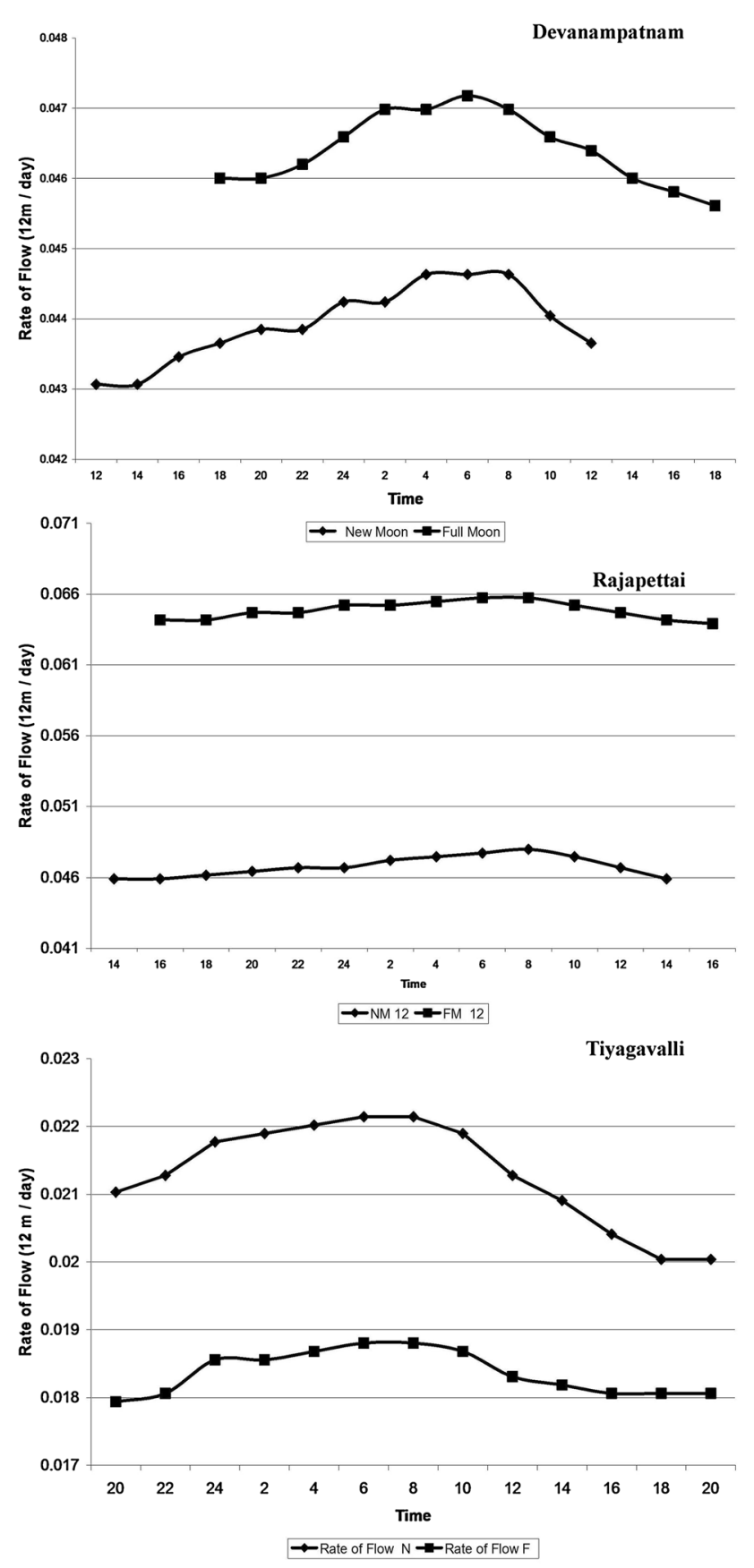

Fig. 8 Variation in Rate of flow during FM and NM at Devanampatnam, Rajapettai and Tiyagavalli

decrease of DO due to monitoring wells by re-oxygenating its water table aquifers that often exhibit low DO concentrations and increases seawater intrusion by tidal effect (Kim et al. 2008; Singaraja 2011; Davies 2014). Tiyagavalli monitoring wells clearly show that high-tide level fluctuates around 08:00 $\mathrm{h}$ and does not correspond to the increase EC. But water level fluctuation corresponding to DO may be due to the influence of freshwater recharge. In this category, there is a clear demarcation of freshwater recharge because the trend of the DO at this location inversely matches with the EC.

\section{Inclination of the water level to the mean sea level}

The inclination of the water table can be calculated by simple Pythagoras method, Where the height of the water level observed, i.e., $\mathrm{AB}$ and the distance of the point of observation to the sea, i.e., AC (Fig. 10) evolving the length of the hypo tense by

$$
\begin{array}{r}
\operatorname{Sin} \emptyset=A B / B C \\
B C=\sqrt{(A B)^{2}+(A C)^{2}} .
\end{array}
$$

The angle of inclination with respect to msl can be calculated by $\mathrm{AB} / \mathrm{BC}(\mathrm{Opp} / \mathrm{hypo}$ tense).

This angle of inclination between the water level nearing the observation well at the measuring point and the MSL is given by the angle $\theta$. The variation in this angle will indirectly indicate the change in water level with respect to the measuring point and the sea. Higher angle shows more variation in water level and vise versa. At Devanampatnam the variation of the angle ranges from $6.284 \times 10^{-5}$ to $6.45 \times 10^{-5}$ degrees during the NM and the angle is maximum around 20:00-10:00 h. Similar observations were also made during FM and it shows that the value of $\theta$ ranges from $6.632 \times 10^{-5}$ to $6.806 \times 10^{-5}$ and the maximum was also around 22:00-12:00 $\mathrm{h}$. The observations indicate that the water level variation with respect to sea was maximum around 22:00-12:00 $\mathrm{h}$ during both the periods and the FM values are higher than the NM, which indirectly influences the rate of flow (Fig. 11).

At Rajapettai the variation of the angle ranges from $6.632 \times 10^{-5}$ to $6.806 \times 10^{-5}$ degrees during the $\mathrm{NM}$ and the angle is maximum around 02:00-10:00 h. Similar observations were also made during $\mathrm{FM}$ and it shows that the value of $\theta$ ranges from $9.25 \times 10^{-5}$ to $9.424 \times 10^{-5}$ and the maximum was around 24:00-10:00 $\mathrm{h}$. The observations indicate that the water level variation with respect to sea was maximum; around 24:00-10:00 $\mathrm{h}$ and the FM values are higher than the NM (Fig. 11). It is also an interesting point to note that the increase of tide, water level, and EC at Devanampatnam and Rajapettai during the NM and FM around 08:00 h corresponds to the decrease of DO due to monitoring wells by re-oxygenating. The observations at Tiyagavalli show that the variation of the angle ranges from $2.967 \times 10^{-5}$ to $3.141 \times 10^{-5}$ degrees during the $\mathrm{NM}$ and the angle is maximum around 20:00-12:00 $\mathrm{h}$ indicating that the angle between the water level at measuring point and the sea is maximum. Similar observations were also made during FM and it shows that the value of $\theta$ ranges from 
Fig. 9 Tidal influence on Devanampatnam, Rajapettai and Tiyagavalli during FM and NM [DO $(\mathrm{mg} / \mathrm{l}), \mathrm{EC}(\mathrm{mS})$, water table and tide $(\mathrm{m})]$
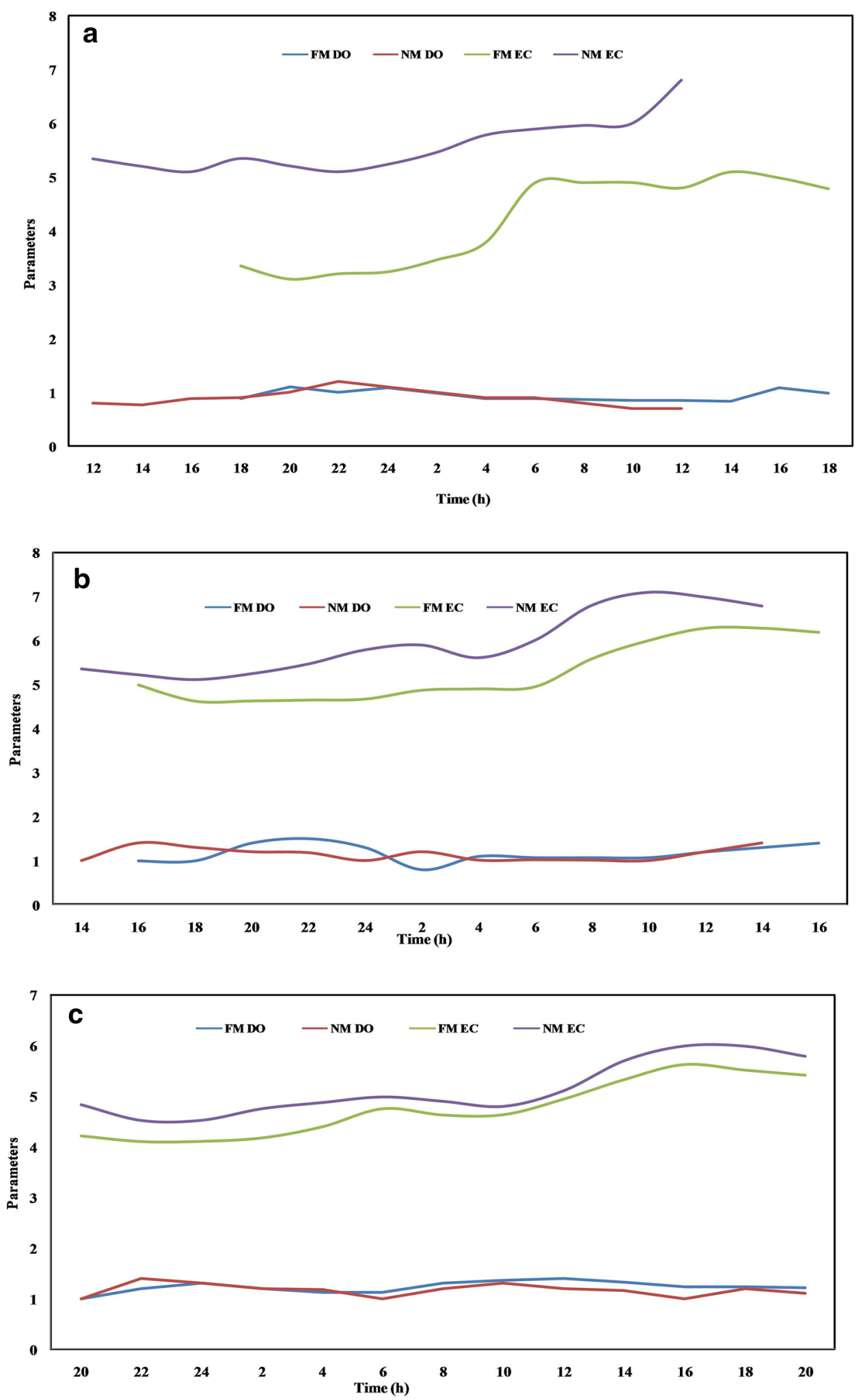

$2.617 \times 10^{-5}$ to $2.792 \times 10^{-5}$ and the maximum was around 04:00 h-12:00 h. The observations indicate that the water level variation with respect to sea was maximum around 04:00-12.00 $\mathrm{h}$ and the NM values are higher than the FM unlike the other two locations (Fig. 11). But water level fluctuation corresponding to DO and inversely matches with the EC may be due to increase of photosynthetic processes from freshwater recharge in river creek. Thus, the variation in 


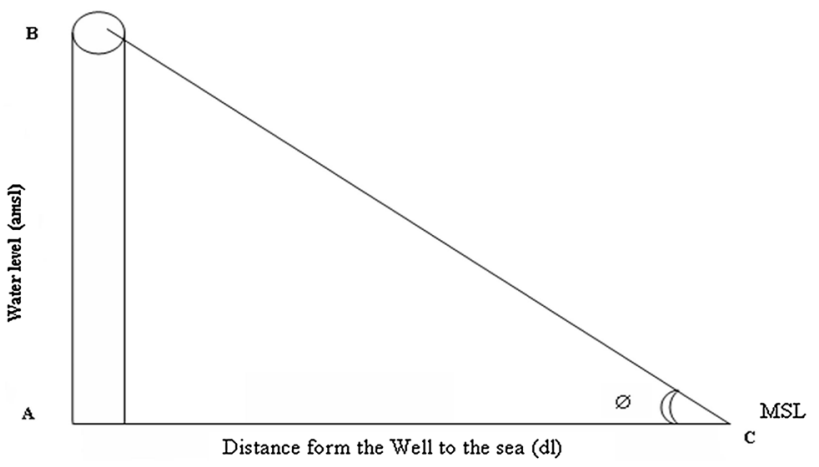

Fig. 10 Inclination of the water level to the mean sea level

the angle helps us to find out that the variation between the water level at the sea and that of the measuring point. It is calculated that for every $1 \mathrm{~m}$ the angular variation in Devanampatnam is $2.847 \times 10^{-5}$, that of Rajapettai is $3.794 \times 10^{-5}$ and that of Tiyagavalli is $1.745 \times 10^{-5}$.

\section{Conclusion}

The above study shows that water level is shallow during the FM compared to the NM at Devanampatnam and Rajapettai. But at Tiyagavalli the NM shows shallow water table than FM. In general water level increases from 14:00 to $08.00 \mathrm{~h}$ and the water fluctuations are higher during the NM than the FM. There is a cyclic decrease and increase of the tidal height which is alternatively witnessed in both NM and FM. There is a tidal fluctuation with time in 6-h interval. Tidal forcing of adjacent groundwater is a common feature in coastal environments and can be an important mechanism of pore water movement in saturated and intertidal zones In general there should be a time lag between the tidal rise and water level rise, but it is interesting to note that there is a simultaneous increase in both tide and water level as the porosity of alluvium is higher and sampling location are very near to the coast. There is an increase of tide, water level fluctuation, and EC at Devanampatnam and Rajapettai during the NM and FM around 08:00 h, but corresponds to the decrease of DO due to re-oxygenating because increases of seawater intrusion by tidal effect. Tiyagavalli well is influence of freshwater recharge due to water level fluctuation corresponding to DO and does not correspond to the increase of EC. The angles of inclination clearly show that rate of flow is higher during FM than NM at Devanampatnam and Tiyagavalli wells by re-oxygenating due to tidal effect. Though the influence of river creek is noted in the ground water in Tiyagavalli due to the increase of photosynthetic processes. Tiyagavalli well varies from certain observations with respect to other two stations. This may be due to the distance of this point of observation to the
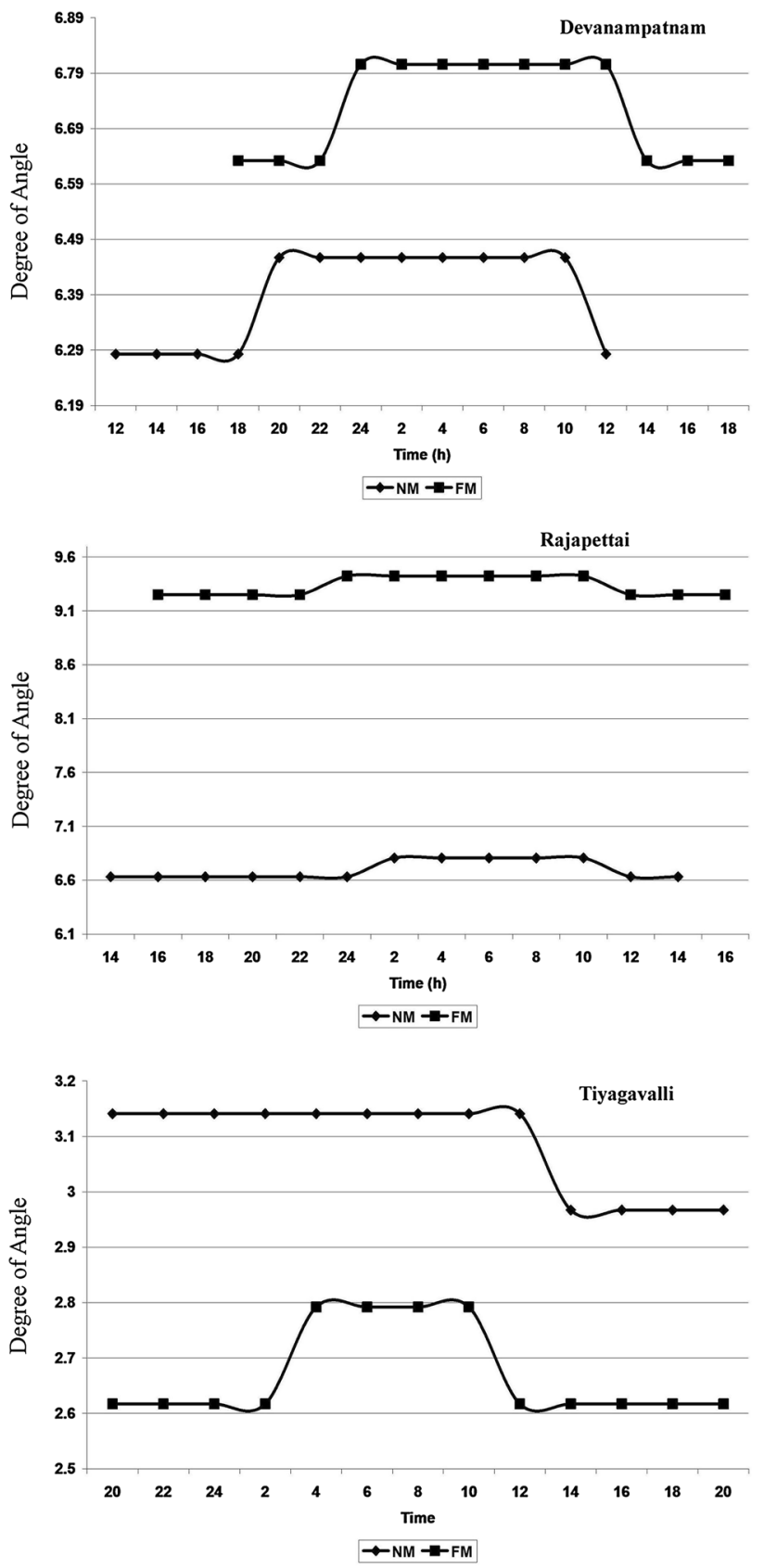

Fig. 11 Inclination of the water level to the mean sea level during FM and NM at Devanampatnam, Rajapettai and Tiyagavalli (in degrees)

sea and influence of river creek. It is calculated that for every $1 \mathrm{~m}$ the angular variation in Devanampatnam is $2.847 \times 10^{-5}$, that of Rajapettai is $3.794 \times 10^{-5}$ and that of Tiyagavalli is $1.745 \times 10^{-5}$.

Open Access This article is distributed under the terms of the Creative Commons Attribution 4.0 International License (http://creativecomm ons.org/licenses/by/4.0/), which permits unrestricted use, distribution, and reproduction in any medium, provided you give appropriate credit to the original author(s) and the source, provide a link to the Creative Commons license, and indicate if changes were made. 


\section{References}

Ashtiani BA, Volker RE, Lockington DA (1999) Tidal effects on seawater intrusion in unconfined aquifers. J Hydrol 216:17-31

Ashtiani BA, Volker RE, Lockington DA (2001) Tidal effects on groundwater dynamics in unconfined aquifers. Hydrol Process 15:655-669

Barlow PM (2003) Groundwater in fresh water-saltwater environments of the Atlantic Coast. U.S. Geological Survey Circular, 1262

Cheng JM, Chen CX (2001) Three Dimensional modelling of densitydependent salt water intrusion in multilayered coastal aquifers in Jahe River Basin, Shandong Province, China. Groundwater 39(1):137-143

Chidambaram S, Ramanathan AL, Prasnna MV, Karmegam U, Dheivanayagi V, Ramesh R, Johnsonbabu G, Premchandar B, Manikandan S (2010) Study on the hydrogeochemical characteristics in groundwater, post- and pre-tsunami scenario, from Portnova to Pumpuhar, southeast coast of India. Environ Monit Assess. 169(1):553-568. https://doi.org/10.1007/s10661-009-1196-y

Davies OA (2014) Tidal influence on the physico-chemistry quality of Okpoka Creek, Nigeria. Int J Biol Sci Appl 1(3):113-123

Davies OA, Ugwumba OA (2013) Tidal influence on nutrients status and phytoplankton population of Okpoka Creek, upper bonny estuary, Nigeria. J Mar Biol Article. https://doi.org/10.1155/2013 /684739

Eriksson KA, Simpson EL, Mueller W (2006) An unusual fluvial to tidal transition in the mesoarchean Moodies Group, South America: a response to high tidal range and active tectonics. Sedim Geol 190:13-24

Harvey JW, Odum WE (1990) The influence of tidal marshes on upland groundwater discharge to estuaries. Biogeochemistry 10(3):217-236

Harvey JW, Germann PF, Odum WE (1987) Geomorphological control of subsurface hydrology in the creekbank zone of tidal marshes. Estuar Coast Shelf Sci 25:677-691

Hughes CE, Binning P, Willgoose GR (1998) Characterisation of the hydrology of an estuarine wetland. J Hydrol 211:34-49

Kim KY, Seong H, Kim T, Park KH, Woo NC, Park YS, Koh GW, Park WB (2006) Tidal effects on variations of fresh-saltwater interface and groundwater flow in a multilayered coastal aquifer on volcanic island (Jeju Island, Korea). J Hydrol 330:525-542

Kim KY, Chon CM, Park KH, Park YS, Woo NC (2008) Multi-depth monitoring of electrical conductivity and temperature of groundwater at a multilayered coastal aquifer: Jeju Island, Korea. Hydrol Process 22:3724-3733

Li H, Boufadel MC, Weaver JW (2008) Tide-induced seawater-groundwater circulation in shallow beach aquifers. J Hydrol 352:211-224

Manoj NT, Unnikrishnan AS, Sundar D (2009) Tidal asymmetry in the mandovi and zuari estuaries, the west coast of India. J Coast Res 25(6):1187-1197

Mao X, Enot P, Barry DA, Li L, Binly A, Jeng DS (2006) Tidal influence on behaviour of a coastal aquifer adjacent to a low-relief estuary. J Hydrol 327:110-127

Marcello N, Mauro G (2007) Tidal, seiche and wind dynamics in a small lagoon in the Mediterranean Sea Estuarine. Coast Shelf Sci 74:21-30

Mitra A, Mondal K, Banerjee K (2011) Spatial and tidal variations of physico-chemical parameters in the lower gangetic delta region, West Bengal, India. J Spat Hydrol 11(1):52-59

Morris DA, Johnson AI (1967) Summary of hydrologic and physical properties of rock and Soil materials as analysed by the Hydrologic laboratory of the U.S. Geologic Survey. US Geol Surv water, Supply Paper 1839-D, p 42
Peter TS, Chandrasekar N, Selvakumar S, Kaliraj S, Magesh NS, Srinivas Y (2014) Tidal effects on estuarine water quality through a sandymarine beach: a case study in Vembar estuary, southeast coast of Tamil Nadu, India. J Coast Sci 1(1):6-14

Philip JR (1973) Periodic nonlinear diffusion: an integral relation and its physical consequences. Aust J Phys 26:513-519

Praveena SM, Siraj SS, Aris AZ, Al-Bakri NM, Suleiman AK, Zainal AA (2013) Assessment of tidal and anthropogenic impacts on coastal waters by exploratory data analysis: an example from Port Dickson, Strait of malacca, Malaysia. Environ Forensics 14(2):146-154

Ramaswamy V, Nath BN, Vethamony P, Illangovan D (2007) Source and dispersal of suspended sediment in the macro-tidal Gulf of Kachchh. Mar Pollut Bull 54:708-719

Robinson MA, Gallagher DL (1993) A model of ground water discharge from an unconfined coastal aquifer. Ground Water 37(1):80-87

Robinson MA, Gallagher DL, Reay WG (1998) Field observations of tidal and seasonal variations in ground water discharge to estuarine surface waters. Ground Water Monit Rem 18(1):83-92

Simmons GM, Von Schmidt-Pauli K, Waller J, Lemourex E (1988) The role of submarine groundwater discharge in transporting nutrient flux to coastal marine environments, Virginia Waters: current developments. Water Resources Research center, V.P.I, Blacksburg, p 52

Singaraja C (2011) Impact of tidal variation in shallow coastal groundwaters of Cuddalore District. Unpublished M Phil Thesis, p 147

Singaraja C, Chidambaram S, Srinivasamoorthy K, Thivya C, Thilagavthi R, Sarathidasan J (2014) Study on the groundwater quality using Watclast program, in coastal aquifers of Cuddalore district. Inventi Rapid Water Environ 1:1-5

Smith L, Zawadzki W (2003) A hydro geologic model of submarine groundwater discharge: Florida inter comparison experiment. Biogeochemistry 66:95-110

Sridevi B, Ramana murty TV, Sadhuram Y, Rao MMM, Maneesha K, Sujithkumar S, Prasanna PL (2010) Impact of internal waves on sound propagation off Bhimilipatnam, east coast of India Estuarine. Coast Shelf Sci 88:249-259

Srinivas K, Dinesh Kumar PK (2002) Tidal and non-tidal sea level variations adjacent ports on the southwest coast of India. Indian J Mar Sci 31(4):271-282

Vethamony P, Reddy GS, Babu MT, Desa E, Sudheesh K (2005) Tidal eddies in a semi-enclosed basin a model study. Mar Environ Res 59:519-532

Wang T, Yang Z, Copping A (2015) A modeling study of the potential water quality impacts from in-stream tidal energy extraction. Estuar Coasts 38(1):173-186

Westbrook SJ, Rayner JL, Davis GB, Clement TP, Bjergd PL, Fisher SJ (2005) Interaction between shallow groundwater, Saline surface water and contamination discharge at a seasonally and tidally forced estuarine boundary. J Hydrol 302:255-269

Wolaver TG, Zieman JC, Wetzel R, Webb KL (1983) Tidal exchange of nitrogen and phosphorus between a mesohaline vegetated marsh and the surrounding estuary in the lower Chesapeake Bay. Estuar Coast Shelf Sci 16:321-332

Publisher's Note Springer Nature remains neutral with regard to jurisdictional claims in published maps and institutional affiliations. 